\title{
Young Women's Aviation, Construction, and Engineering Academy
}

\author{
OraLynn Manweller, Amy Hoover, William Bender \\ Central Washington University
}

\begin{abstract}
The Young Women's Aviation, Construction and Engineering (ACE) Academy was instituted this year at Central Washington University. Our goal is to increase the number of young women who choose to pursue education and enter the workforce in these technical fields. The Academy is a 3-day, 2-night summer weekend academy that provided hands on learning experiences and activities to spark career interest in these fields. The academy will be offered in subsequent years, and the success of the program will be evaluated after three years.

Introduction

Central Washington University (CWU) is a state-supported university that serves approximately 8,000 students, including graduate students. In the Industrial and Engineering Technology department, there are eight majors offered to students. Among these choices are Mechanical Engineering Technology, Flight Technology and Construction Management. In all of these programs, women are underrepresented. It became important to work towards a more diverse composition of students. The ACE Academy evolved from this necessity.
\end{abstract}

In the summer of 2004, 23 girls (age 13-16) were accepted at the workshop. Next year, the camp will be expanded to 36 . The academy begins on a Friday afternoon with girls getting to know each other and learning what the weekend is all about. Saturday and Sunday morning consists of workshops where the girls are exposed to each of the three professions (aviation, construction, and engineering). They spend four hours examining each career option, with no more than twelve girls in each group. The activities range from flying an airplane to designing a pop bottle rocket. The program culminates with an award ceremony where friends and family have an opportunity to see what the girls have accomplished over the weekend.

The cost of the camp is about $\$ 150$ per girl, of which the girls pay $\$ 25$. The rest of the funds have been raised from donations and grants. Some companies have donated materials, such as airplanes and instructors. Others have sponsored daughters of their employees. Funds were even received from individuals that felt this was a worthy cause. Many professional women from the community volunteered to help with the academy in order to provide the girls with positive female role models. They helped with the workshops and even slept in the dorms with the girls. In the future we expect to increase the grant money in order to accept more girls for the academy.

A survey was taken at the end of the academy to gauge the initial response to the program. The results of this initial survey will be discussed within the paper. Additionally, the paper will 
describe the format of the program, the educational itinerary, and plans to broaden the goals of the program. In an effort to gauge the success of the program, we plan to track the progress and the educational choices the girls make after high school. It is hoped that this program will encourage young women to seriously consider the professions of engineering, aviation and construction.

The goal of the ACE Academy is to increase the number of women that choose to enter these technical fields. By introducing girls to these fields at a younger age that they will be more likely to enter these career paths as they enter college. In order to intrigue the girls, we chose to prepare a weekend academy for the girls to learn about these careers and what they offer. At the end of the weekend, a survey was taken to learn what the girls thought about the academy and what they would like to see changed for next year. Below is a sample of the agenda for the weekend.

Schedule of Activities

\begin{tabular}{|l|l|l|}
\hline Friday & Saturday & Sunday \\
\hline $\begin{array}{l}\text { Arrival and registration 3:00 } \\
-5: 00\end{array}$ & Early breakfast & Early breakfast \\
\hline $\begin{array}{l}\text { 5:00-6:00 Reception and } \\
\text { presentation with industry } \\
\text { professionals }\end{array}$ & $\begin{array}{l}\text { 8:00-11:50 Construction, } \\
\text { Engineering, or Aviation }\end{array}$ & $\begin{array}{l}8: 00-11: 50 \text { Construction, } \\
\text { Engineering, or Aviation }\end{array}$ \\
\hline $\begin{array}{l}\text { 6:00 - Dinner and evening } \\
\text { event (Communication) }\end{array}$ & $\begin{array}{l}1: 00-4: 50 \text { Construction, } \\
\text { Engineering, or Aviation }\end{array}$ & $\begin{array}{l}1: 00-2: 00 \\
\text { Closing reception }\end{array}$ \\
\hline & $\begin{array}{l}\text { 6:00 - Dinner and Evening } \\
\text { event (Water Rockets) }\end{array}$ & \\
\hline
\end{tabular}

Need

Women are under represented in the professions of aviation, construction and engineering. According to the U.S. Bureau of Labor Statistics ${ }^{1}$, women make up $49 \%$ of the professional work force. However, only $6 \%$ of aviation professionals are women ${ }^{2}, 10 \%$ of construction professionals are women ${ }^{3}$ and $10 \%$ of engineering professionals are women ${ }^{1}$.

Several programs currently sponsor professionals who go into middle and high schools to introduce young people to the technical professions. Despite the efforts of these technical communities, enrollment of women in non-traditional professional degree programs has grown by only 4 percent during the $1990{ }^{\prime}{ }^{4}$. This may be due to the lack of direct hands on interactive experience for these young women to explore those fields.

A workshop format has been selected for this project because it provides an interactive delivery and has been shown to be an effective methodology to allow participants to make informed decisions ${ }^{5}$. A workshop offers the opportunity to have a captive audience doing fun activities to generate interest in technical career fields. This project synergistically combines existing programs and industry professionals at a centrally located regional university to develop and support the establishment of this workshop.

"Proceedings of the 2005 American Society for Engineering Education Annual Conference \& Exposition Copyright (C) 2005, American Society for Engineering Education" 
Recruitment

Since this was the first year of the ACE Academy, it was decided to recruit girls mostly from the central part of the state of Washington. Representatives of the academy traveled to various schools to present the information about the ACE Academy. Flyers were also sent out to schools to promote the program. In an effort to include as many girls as possible, the fee for attendance was kept to $\$ 25$. This allowed girls from all income levels to participate, but it also showed which girls were actually serious about attending. If there was not a fee, it would be possible for girls to sign up, but never attend. It was necessary to have a way to know whether the girls would attend or not for planning reasons.

\section{Aviation}

A female flight technology professor led the aviation portion of the academy. In order to demonstrate the possibilities offered in this field, the girls were given a short (30 min) overview of aviation, where they had a chance to talk with women that are professionals in this field, such as an army helicopter pilot. This gave the girls a basic understanding of what the career can offer to anyone that is motivated.

The girls were then led through a short demonstration of a pre-flight check, which each girl completed before having the chance to go on a short flight with a licensed pilot. A local company, Midstate Aviation, donated the plane, instructor and all costs. This experience gave the girls the chance to truly experience the field of aviation on their first flight lesson.

\section{Construction}

A female professor from Washington State University conducted the construction sessions. This session began with both professionals in the industry and students currently involved in the Construction Management program at CWU. This gave the girls an understanding of what the career is like, as well as the training that is necessary to enter this profession.

After the discussion, the girls had the opportunity to visit a construction site on campus. The music building was nearing completion, so the girls were able to see a construction site and learn about the different tasks that had to be completed for a building to be built and pass inspection by the city.

Finally, the girls were taught a little bit about stress and force. They learned how to calculate stress from an applied tensile force. The girls calculated the force necessary to break a specimen, and then used a tensile tester to break the piece and compare the force calculated to the force that was actually used.

\section{Engineering}

In the engineering session, led by a female mechanical engineering technology student, the goal was to show the girls the different types of engineering and give them a taste of what engineering 
is all about. The session began with a group of women engineers telling the girls about their current and previous jobs, what they liked about it and what led them to choose this profession. The girls were then given pamphlets describing each of the major types of engineering and a discussion ensued, giving the girls an opportunity to talk about engineering and ask questions about what they didn't understand.

After a short break, the girls had the opportunity to see a hydrogen fuel cell that had been donated to the department. Students that had been working on the fuel cell, which described the technology of a fuel cell and showed how the fuel cell works, gave a presentation. This demonstrated one of the new technologies that is being designed by engineers, which gave them an idea of possibilities that they could be involved in if they became engineers.

Finally, it was important for the girls to see how fun engineering can be, so they participated in an egg drop competition. They were given a limited amount of materials and time, and then they were expected to drop their contraption from varying heights to determine which design could support the egg best. In the end, there were several designs where the egg never broke, showing the ingenuity of the girls. After the exercise, it was discussed how this relates to realistic designs, such as air bags.

\section{Evening Activities}

Given the career paths that were being presented, it was important to have hands-on activities. Therefore, the evening activities involved an activity that was hands-on, as well as educational. The first night activity centered on communication and the girls getting to know each other. In this activity, the girls were divided into two groups. Each group was given two boxes of k'nex toys, with identical pieces in each box. Each group was then subdivided into four sub-groups. The first sub-group was given the task of building an object using the k'nex toys. The second subgroup could see the apparatus that was being built. They then relayed this information to the third subgroup, which could not see the apparatus. Their job was to further relay the information to the fourth group where the apparatus was to be duplicated. All of the girls were given an allotted time and at the end the two apparatuses were compared.

The lesson in this exercise was communication. Many people think that these careers are only about math and science, but there is also a critical communication component. This activity showed the girls the importance of good communication.

The second night, Saturday, the girls designed and fired-off water rockets. The girls were divided into groups of two and each group was given a two liter pop bottle. Their task was to make the bottle into a rocket, using provided materials. Each group added a nose cone and fins to the bottle. Some girls were more creative in the design than others. Each bottle was then partially filled with water, attached to a launching pad, further filled with water and then released. The horizontal distance was then measured. Most of the groups traveled about 100150 yards. However, there were two groups that managed to fly over 400 yards. 
This activity showed the girls that there are times for creativity and times for practicality. Each rocket was beautifully designed, but when they were launched there were varying results. This experience showed them the trade-offs that are inherent in design.

\section{Survey Results}

On the final day, Sunday, the girls and their families gathered for a reception to wrap up the camp. Among other things, the girls were asked to fill out a short survey, evaluating the camp and making suggestions for the following year. The girls were asked four questions, which were:

1. What did you like most about the camp?

2. What did you like least about the camp?

3. What was your favorite session?

4. What was your favorite session activity?

On the first question, the most common answer was flying an airplane, with 18 of the 22 surveys listing that as their favorite part of the weekend. However, eight of the 18 also mentioned that they liked other activities, all of which were hands-on activities. The other four of the 22 surveys said that they enjoyed the evening activities the best. This shows that the attempt to include hands-on activities was a valuable part of the academy.

The second question revealed a similar trend. The surveys showed that the girls did not like sitting and listening to lectures. 16 surveys indicated that the lectures went on too long. Seven surveys mentioned that they disliked the dorm rooms because there was no air conditioning. One survey said that "nothing" was wrong with the camp and one survey said that the girl was too tired to stay awake. This question also demonstrated the need for hands-on activities and fewer lectures.

When asked about their favorite session, 16 surveys mentioned only aviation, two said just engineering, three liked both aviation and engineering and one survey indicated that she liked aviation and construction. This corresponds with the first question, which showed that flying was the girls' favorite part of the camp.

The last question revealed that the girls seemed to enjoy many of the activities. Seven surveys claimed that their favorite activity was flying the airplane. One survey said they enjoyed the tour of the construction site. Four girls liked the egg drop. Three preferred the rocket launch. One girl wrote that she liked both the rocket launch and the egg drop. Four girls liked the flying and the egg drop. The remaining three wrote that they liked the rocket launch, the egg drop and the flying.

\section{Future Efforts}

After reviewing the surveys, it became evident that the girls thoroughly enjoyed the hands-on activities, and especially the chance to fly an airplane. This indicates that the program is headed in the right direction. In the future it will be important to include more activities, while keeping the favorites from this year. The rocket launch, egg drop and flying an airplane will remain a 
staple of the academy from year to year. However, it is also evident that the lectures need to be decreased in length and air conditioning is a necessity, when available. Next year it is planned to implement these changes as much as possible. Unfortunately CWU does not offer airconditioned dorm rooms, so the camp is being held earlier in the summer.

Because this was the first year that the ACE Academy was conducted, it was difficult to obtain data that would gauge the success of the program, with regard to encouraging women to enter the fields of construction, aviation and engineering. In the future it is planned to conduct further surveys to follow the girls through high school and into college. It is suspected that these girls will be more likely to enter technical fields when they enter college.

\section{Conclusion}

After reviewing the surveys completed from the girls, it appears that the academy was a success. The girls seemed to have a good time and learn a lot about these technical fields. The hands-on activities were listed on the surveys as a positive aspect of the camp. This shows that the camp is headed in the right direction for attracting girls to these fields. It is planned to continue this program for at least two more years. At the end of that time the success of the program will be evaluated to determine if it should be continued.

Bibliography

1. Bureau of Labor Statistics (2004). Household data annual averages, retrieved January 20, 2004 from http://stats.bls.gov/cps/cpsaat9,pdf

2. Women in Aviation (2004). Women in aviation, the facts, retrieved March 17, 2004 from https://www.wai.org/resources/facts.cfm

3. ENR (2003). In Support of Women, Engineering News Record, 6 October 2003, McGraw-Hill Publishing, New York, NY

4. Septelka, D. (1999). Schools failing to attract women into construction, Seattle Daily Journal of Commerce, retrieved March 17, 2004 from www.djc.com/news/const/10057680.htm

5. Decker, D., Lassoie, J., Goff, G., Parrish, K., (1998). Do Workshops Work? Journal of Extension, retrieved January 20, 2004 from http://www.joe.org

\section{ORALYNN MANWELLER}

OraLynn Manweller is a senior in Mechanical Engineering Technology at Central Washington University in Ellensburg, WA. She received her AS from Lane Community College in Eugene, OR in 2003. She will be graduating from CWU in June. She has been involved with planning and implementing the engineering portion of the ACE Academy from the beginning.

\section{AMY HOOVER}

Amy Hoover is an Assistant Professor of Flight Technology at Central Washington University in Ellensburg, WA. She is a licensed pilot. She received her Masters in Geology in 1987 from Oregon State University. She is currently working a PhD in Education/Industrial Engineering from Oregon State University. She is the co-director of the ACE Academy. 


\section{WILLIAM BENDER}

William Bender is an Associate Professor of Construction Management at Central Washington University in Ellensburg, WA. He received his PhD from University of Maryland, College Park in 2001. He is a registered professional engineer in the state of Washington. He is co-director of the ACE Academy. 